\title{
Predicting and Mapping Soil Available Water Capacity in Korea
}

The knowledge on the spatial distribution of soil available water capacity at a regional or national extent is essential, as soil water capacity is a component of the water and energy balances in the terrestrial ecosystem. It controls the evapotranspiration rate, and has a major impact on climate. This paper demonstrates a protocol for mapping soil available water capacity in South Korea at a fine scale using data available from surveys. The procedures combined digital soil mapping technology with the available soil map of 1:25,000. We used the modal profile data from the Taxonomical Classification of Korean Soils. The data consist of profile description along with physical and chemical analysis for the modal profiles of the 380 soil series. However not all soil samples have measured bulk density and water content at -10 and -1500 kPa. Thus they need to be predicted using pedotransfer functions. Furthermore, water content at $-10 \mathrm{kPa}$ was measured using ground samples. Thus a correction factor is derived to take into account the effect of bulk density. Results showed that Andisols has the highest mean water storage capacity, followed by Entisols and Inceptisols which have loamy texture. The lowest water retention is Entisols which are dominated by sandy materials. Profile available water capacity to a depth of $1 \mathrm{~m}$ was calculated and mapped for Korea. The western part of the country shows higher available water capacity than the eastern part which is mountainous and has shallower soils. The highest water storage capacity soils are the Ultisols and Alfisols (mean of 206 and 205 mm, respectively). Validation of the maps showed promising results. The map produced can be used as an indication of soil physical quality of Korean soils. 
Title of manuscript:

\section{Predicting and Mapping Soil Available Water Capacity in Korea}

Suk Young Hong,

National Academy of Agricultural Science, Rural Development Administration (RDA), Suwon 441-707, Gyeonggi-do, Republic of Korea.

Budiman Minasny,

Department of Environmental Sciences, Faculty of Agriculture and Environment, The University of Sydney, NSW 2006, Australia.

Kyung Hwa Han,

National Academy of Agricultural Science, Rural Development Administration (RDA), Suwon 441-707, Gyeonggi-do, Republic of Korea.

Yihyun Kim,

National Academy of Agricultural Science, Rural Development Administration (RDA), Suwon 441-707, Gyeonggi-do, Republic of Korea.

Kyungdo Lee

National Academy of Agricultural Science, Rural Development Administration (RDA), Suwon 441-707, Gyeonggi-do, Republic of Korea.

\section{Corresponding author:}

Budiman Minasny,

Department of Environmental Sciences, Faculty of Agriculture and Environment, The University of Sydney, NSW 2006, Australia. Ph. +61 28627 1131. E-mail: budiman.minasny@syney.edu.au 


\section{Introduction}

There is a global increase in demand for soil data and information for quantitative environmental monitoring and modelling (Dunne \& Willmott, 1996; Hartemink, 2008). Accurate, up-to-date and spatially referenced information on soil properties and processes is essential for within-field, catchment, regional, continental and global food, environmental, and ecosystem management (Batjes, 1996; Dunne \& Willmott, 1996; Hartemink \& McBratney, 2008; Holmes et al., 2004, Wösten et al., 2013). Digital soil mapping has modernised the way soil properties are mapped (Malone et al., 2009; McBratney et al., 2002; Terribile et al., 2011). This coincides with an enormous leap in technologies that allow accurate measurement and prediction of soil properties (Mulder et al., 2011; Triantafilis, Kerridge \& Buchanan, 2009). Accordingly, there is a global need for making a new digital soil map of the world using state-of-the-art and emerging technologies, which enable estimation of soil properties at a fine resolution through the GlobalSoilMap project (Sanchez et al., 2009).

Characterisation of available water capacity (AWC) of soil is important for assessing the soil's physical status and quality. Furthermore, available water capacity is a component of the water and energy balances of terrestrial biosphere (Milly \& Shmakin, 2002), and is required in ecological studies to establish the response of plant or animal species or communities to environmental conditions (Basson \& Terblanche, 2010; Piedallu et al., 2011). The availability of soil moisture controls the rates of evaporation and transpiration, which in turn can have a major impact on climate. It also controls hydrologic processes such as groundwater recharge, infiltration and overland flow. Soil water holding capacity is one of the most important soil factors for plant growth, influencing carbon allocation, nutrient cycling, and the rate of photosynthesis. Many studies have developed pedotransfer functions (PTFs), which predict soil hydraulic properties such as water retention at field capacity and wilting point from basic soil properties (McBratney et al., 2002; Nemes, Pachepsky \& Timlin, 2011; Saxton and Rawls, 2006; Wösten et al., 2011). However fewer studies have mapped available water holding capacity (Wösten et al., 2013). At a field extent, Zheng, Hunt \& Running (1996) used topographic wetness index as a surrogate for profile available water capacity (PAWC) in three areas in the state of Montana, USA. Leenhardt et al. (1994) evaluated the effectiveness of soil maps at different scales in predicting PAWC, and found that maps at 1:10,000 and 1:25,000 provided good estimates of soil physical properties. Cazemier, Lagacherie \& Martin-Clouaire (2001) mapped PAWC in a field in south of France using a 
combination of two different types of information available in soil databases: imprecise descriptions of soil classes, and pedotransfer functions. At a regional extent, Malone et al. (2009) mapped PAWC in the Edgeroi area in New South Wales, Australia using the regression kriging method. Meanwhile, Poggio et al. (2010) addressed the issue of uncertainty in the spatial prediction using geostatistical simulation techniques at catchment, regional and national scales in Scotland. At a continental extent, Kern (1995) estimated profile PAWC in the USA based on pedotransfer function and soil map. Finally, at a global extent, Batjes (1996) produced estimates of global PAWC at a resolution of $0.5^{\circ} \times 0.5^{\circ}$ using a global database and soil map of the world. In a separate study, Dunne \& Willmott (1996) established a global PAWC map based on the FAO soil map. These global maps were used in various global models on climate, terrestrial biosphere, and hydrology (Knorr \& Heimann, 2001; Milly \& Shmakin, 2002; Nijssen et al., 2001; Tao et al., 2003; Walter, Heimann \& Matthews, 2001).

As recently lamented by Terribile et al. (2011), how can soil data from available soil mapping databases be used effectively for hydrological modelling? This paper will attempt to illustrate the procedures for mapping soil available water capacity in Korea using available national scale database and maps. In Korea there is a need for detailed information on available water capacity for agricultural and environmental modelling purposes. While digital mapping techniques have been used in Korea to map soil erosion risk (Jung et al., 2004; Jung et al., 2005; Park et al., 2011), and landslide susceptibility (Lee et al., 2012), we need an estimate of the water holding capacity for the whole peninsula. The objective of this study is to estimate and map soil available water capacity of Korea using digital soil mapping techniques. In doing so, we will develop pedotransfer functions that predict bulk density, field capacity and wilting point.

\section{Materials and Methods}

\section{Geography and soil data}

This study considered the mainland of South Korea, excluding some smaller islands, such as Ulleung, and Dokdo. The area is approximately 100,000 $\mathrm{km}^{2}$, lies between $33.931^{\circ} \mathrm{N}$ and $38.705^{\circ} \mathrm{N}$ and $125.436{ }^{\circ} \mathrm{E}$ and $129.705^{\circ} \mathrm{E}$. Korea is located in the humid temperate climatic zone, affected by the influence of both continental and oceanic air masses. National mean 
annual rainfall is 1,300 mm, ranging from $980 \mathrm{~mm}$ (Daegu area) to 1,440 $\mathrm{mm}$ (Cheju area). Approximately half of the annual rainfall occurs during the summer months, June to August, with occasional typhoons. During the summer, although the ambient temperature is high (mean temperature; $20-25^{\circ} \mathrm{C}$ ), and crop canopies are thick, the precipitation exceeds the potential evapotranspiration because of concentrated heavy rainfall. As a result, the base saturation ratios in the majority of soils are rather low. Temperatures in the spring and autumn are mild (mean temperatures of $10-15^{\circ} \mathrm{C}$ ) and winter months are rather cold (monthly mean temperature of $-5-2^{\circ} \mathrm{C}$ ), particularly in the central and northern regions. In the winter, spring and autumn, the precipitation is less than in the summer. Despite these seasonal differences, the amount of precipitation and the potential evapotranspiration remain similar year round because of the lower ambient temperatures in the drier seasons.

Korea is a mountainous country. More than two-thirds of the country is occupied by mountains with steep slopes. Plains are subdivided into inland plains, coastal plains and the plains in the narrow valleys. The plains had been under intensive use for agricultural production. The high relief of the land coupled with the heavy downfalls of rain in the summer affects the characteristics of Korean soil very profoundly. Soil erosion has been intense throughout the country for a long time, particularly where the population density is high.

The parent materials of Korean soils are part of the ten recognised geologic systems from different geological time series. Dominant rock types include granitic gneiss (32.4\%), granite (22.3\%), schist (10.3\%), limestone of the Chosun series (Cambrian-Ordovician; 10.1\%). The former three geological systems are present in about $60 \%$ of the land area and are known as acidic rocks. The fact that the rainfall exceeds the potential evapotranspiration and coupled with the abundance of acidic rocks, results in the wide occurrence of acidic soils in the country. The limestones of the Chosun series are alkaline, thus the soils derived from these rocks tend to be neutral or slightly alkaline. These soils are only found near Kangwon Province. Some areas contain sandstone bedrock which results in coarse-textured soils. However, even among the soils derived from the same parent rock, the textures can vary depending upon the location in the soil catena. Soils developed in high elevation areas tend to be coarse due to severe loss of fine particles by erosion, while the soils developed at the locations where soil erosion is not severe tend to be fine-textured. Given, the high variation of soil as function of climate, topography, parent materials and landuse, it is a challenge to produce estimates of soil properties at a fine resolution. 
The soil survey was initiated by the Korean Rural Development Agency (RDA), UN, and FAO with a reconnaissance survey, making use of aerial photographs purchased from USA funded by Korea Soil Survey Organization between 1964 and 1967. As a result, soil maps of Korea at scales of 1:250,000 and 1:50,000 were published. Thereafter, RDA adopted the US Soil Taxonomy system and carried out the detailed soil survey between 1968 and 1990 alone. Now, detailed soil maps $(1: 25,000)$ are available for entire country in both hard copies and digital format. Furthermore, RDA prepared highly detailed soil maps (1:5,000) between 1995 and 1999 for the entire country. These were digitized and made available for the public through the RDA web site (http://soil.rda.go.kr).

The soil database used in this study was compiled based on the soil profiles in "Taxonomical Classification of Korean Soils” (NIAST, 2000), which were mostly collected in the 1970s. It includes soil profile descriptions along with physical and chemical analysis for the modal profiles of the 380 soil series defined in South Korea. Soil chemical and physical properties of each horizon $(n=1,559)$ were recorded, including particle size distribution, moisture retention, organic matter content (OM), cation exchange capacity (CEC), and a limited number of bulk density (BD) data. Soil water retention was recorded for water content at -10 , -33 and $-1500 \mathrm{kPa}$ on the mass basis ( $\mathrm{w}$ in $\mathrm{g} 100 \mathrm{~g}^{-1}$ ) using soils that were ground and sieved to $<2 \mathrm{~mm}$. The statistics of the data is given in the Supplementary Materials (T1). The data show a wide range of distribution for bulk density and water retention. The low bulk density and high water retention soils are due to the Andisols, while the high bulk density and low water retention soils are due to Entisols which have a high sand content (>70\%).

A couple of problems arise in using this database to map the AWC:

- Not all soil samples have measured bulk density and w at -10 and -1500 kPa. Thus they need to be predicted using pedotransfer functions

- Water content (w) at -10 kPa in the database was measured using disturbed (ground) samples. Thus a correction factor is needed to take into account the effect of bulk density.

\section{Prediction of bulk density}

Only 108 samples contain measured BD, so first we derived a linear model predicting bulk density as a function of organic matter (OM) and sand content. While this model has a 
reasonable predictive capacity $\left(\mathrm{R}^{2}=0.59\right)$, when we applied this model to the whole datasets, we obtained unreasonable estimates of values between -2.00 to $2.50 \mathrm{~g} \mathrm{~cm}^{-3}$. Therefore we used a more conceptual function as proposed by Tranter et al. (2007) which first estimated the mineral bulk density, $\mathrm{BD}_{\min }$ as a function of sand content and soil depth. This estimate is then combined with the BD model of Adams (1973) which incorporated the effect of organic matter (OM). Andisols which contain a high amount of allophanic materials can have a different response to the model. Therefore we derived a separate model for BD for Andisols using a global dataset (Tempel, Batjes \& van Engelen, 1996).

\section{Pedotransfer functions predicting field capacity and wilting point}

Available water capacity is defined here as the amount of water held by the soil between field capacity and wilting point. Water content at field capacity is usually measured in laboratory at a potential of -10 or $-33 \mathrm{kPa}$. Here we use water content at $-10 \mathrm{kPa}$ to represent field capacity, and at $-1500 \mathrm{kPa}$ for wilting point. Although field capacity is more of a dynamic property which depends on the soil's hydraulic conductivity (Romano, Palladino \& Chirico, 2011), because of the unavailability of field measurement, we only used the laboratory data.

In the absence of laboratory measurement, water content at field capacity can be predicted using pedotransfer functions from the soil's particle size distribution, and bulk density or soil structural information (McBratney et al., 2002; Saxton and Rawls, 2006). Here we developed a linear regression model predicting gravimetric water content at $-10 \mathrm{kPa}\left(\mathrm{w}_{10}\right)$ and $-1500 \mathrm{kPa}$ $\left(\mathrm{W}_{1500}\right)$ measured on ground soil samples using basic soil information: clay content, sand content, organic matter content (OM) and cation exchange capacity (CEC):

$$
\mathrm{w}_{10,1500 \mathrm{gr}}=\mathrm{f}(\text { sand, clay, OM, CEC). }
$$

\section{Adjustment of field capacity according to bulk density}

Water content at field capacity is affected by macroporosity and soil structure (Sharma \& Uehara, 1968), and therefore measurement is recommended using natural soil clods. Meanwhile water content at wilting point or $-1500 \mathrm{kPa}$ is not much affected by structure, as most water is held with adsorptive forces, thus it can be measured using disturbed soil samples (Aina \& Periaswamy, 1985). However in the Korean soil database, water content at 
$-10 \mathrm{kPa}$ was measured on ground samples. This is because the samples collected from soil survey were mainly for mapping and classification purposes, and samples for bulk density and soil clods were not collected. This problem is also common in other countries (Bell \& Van Keulen, 1996). Bell \& Van Keulen (1996) warned against the use of field capacity data derived from disturbed samples as its measurement overestimates in-situ field capacity for most soils except for coarser textured soils.

Thus water retention data in the Korean soil database which were measured on ground samples need to be adjusted to represent the likely water content at a given bulk density. To build such a model, the only publicly available data that contained such measurements is the soil characterization and profile data from the US National Soil Characterization database (Soil Survey Staff, 1997). 301 samples in the database contained water content at -10 kPa measured using both natural clods and disturbed samples. From this subset, 274 samples were selected for building the model and the rest (27 samples) were used as validation data. The data are from 141 profiles, and the samples come from A, B and C horizons from various depths in the top $2 \mathrm{~m}$ of the profile.

The statistics of the soil properties from the US database is given in Supplementary Materials (T2). The database contained measurements of $\mathrm{w}_{10}$ clod, the percent mass of water retained at suction of $10 \mathrm{kPa}$, which was measured on natural fabric (clods), and reported on a $<2 \mathrm{~mm}$ base. $\mathrm{w}_{10}$ ground is the gravimetric water content of air dry $<2 \mathrm{~mm}$ (ground) samples, after equilibration at $10 \mathrm{kPa}$ suction. BD is the bulk density $\left(\mathrm{g} \mathrm{cm}^{-3}\right)$ of the $<2 \mathrm{~mm}$ fraction, with volume being measured after equilibration at $-10 \mathrm{kPa}$. We used a linear regression to obtain the estimates of $\mathrm{w}_{10}$ clod from $\mathrm{w}_{10}$ ground plus other basic soil properties.

\section{Prediction of profile available water capacity}

After adjustment of water retention at $-10 \mathrm{kPa}$ for bulk density, available water capacity for each layer is calculated as the difference in volumetric water content $(\theta)$ between field capacity and wilting point, adjusted by gravel content:

$$
\operatorname{AWC}(\mathrm{mm})=\left(\theta_{10}-\theta_{1500}\right) / 100 \times\left(1-\mathrm{R}_{\mathrm{v}}\right) \times \text { Thickness of layer }(\mathrm{mm})
$$

Where volumetric water content ( $\theta$ in percent volume) is calculated from gravimetric water content (percent mass) multiplied by bulk density (in $\mathrm{g} \mathrm{cm}^{-3}$ ): 


$$
\theta=\mathrm{w} \times \mathrm{BD} .
$$

$\mathrm{R}_{\mathrm{v}}$ is the volume fraction of gravel $\left(\mathrm{m}^{3} \mathrm{~m}^{-3}\right)$, calculated from Saxton and Rawls (2006):

$$
R_{v}=\frac{\alpha R_{w}}{1-R_{w}(1-\alpha)}
$$

where $R_{v}$ is the mass fraction of gravel $\left(\mathrm{kg} \mathrm{kg}^{-1}\right)$, and a is the ratio of soil to gravel density (BD/2.65). The PAWC (profile available water capacity in $\mathrm{mm}$ ) is calculated as the sum for all the layers up to $100 \mathrm{~mm}$ :

$$
P A W C=\sum_{i=1}^{n} A W C_{i}
$$

The procedure for estimation of PAWC is summarised in Figure 1.

Figure 1 near here

\section{Mapping}

The map of the available water capacity to 1 meter depth (PAWC) was made by calculating the modal PAWC value for each of the South Korean soil series. The modal values for each soil series were then allocated to each of the map units of the 1:25,000 map. An equal-area spline was utilised to represent the continuous soil depth function of AWC. The equal-area spline function not only fits the water content data with depth, but also disaggregates data obtained from horizon bulk samples into a continuous depth distribution. The spline function consists of a set of local quadratic functions tied together with 'knots' that describe a smooth curve through a set of points. These functions are advantageous for harmonizing soil properties that were collected at different depths. See Malone et al. (2009) for the mathematical detail of the functions.

\section{Map validation}

An independent dataset was used to validate the map predictions. The map validation dataset comprises measurement from 170 soil profiles representing 165 soil series. These profiles were collected recently in 2009 and 2011. As the samples were collected for soil survey 
purposes, no water retention measurement was made, however the data contains measurement of particle size analysis and bulk density. We can therefore validate the maps of bulk density, clay and sand content. These variables are the important predictors of available water capacity. The validation was performed on 5 standard depths where the soil samples were measured: $0-5,5-15,15-30,30-60$, and $60-100 \mathrm{~cm}$. The prediction from the map was resampled to these standard depths using the equal area spline function.

To validate the prediction of water content at field capacity, another published dataset was used (Han et al, 2008a; Han et al, 2008b). This dataset, here called water retention validation dataset, is a collection of 18 mostly topsoil $(0-20 \mathrm{~cm})$ samples, representing 7 soil series. The samples were measured for soil hydraulic properties using an undisturbed soil core with the onestep outflow technique, and water content at $-10 \mathrm{kPa}$ was calculated (see Supplementary materials $\mathrm{T} 3$ for the description of the dataset).

\section{Results and Discussion}

PTF for bulk density

Following Tranter et al. (2007), we first derived a pedotransfer function (PTF) predicting mineral bulk density $\left(\mathrm{BD}_{\min }\right)$ from sand content and depth based on the limited data in the database $(n=108)$ :

$$
\mathrm{BD}_{\min }=1.017+0.0032 * \text { Sand }+0.054 * \log (\text { depth })(5)
$$

where depth is the mean depth of the sample $(\mathrm{cm})$ and Sand is the percentage by mass of sand $\left(\mathrm{g} 100 \mathrm{~g}^{-1}\right)$. The coefficient of determination $\left(\mathrm{R}^{2}\right)$ is quite low $(0.20)$ as this model only accounts for the influence of the mineral component and overburden. The influence of organic matter on bulk density is then calculated based on the model of Adams (1973):

$$
B D=\frac{100}{\frac{O M}{B D_{O M}}+\frac{100-O M}{B D_{\min }}}
$$

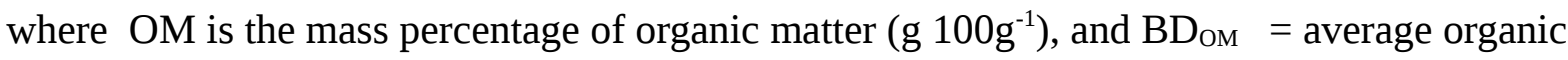
matter bulk density $=0.224 \mathrm{~g} \mathrm{~cm}^{-3}$, and $\mathrm{BD}_{\min }$ is the mineral bulk density $\left(\mathrm{g} \mathrm{cm}^{-3}\right)$. 
Because of the different mineralogical composition of Andisols, a separate model that predicted BD from OM content was derived from the Tempel, Batjes \& van Engelen (1996) dataset:

$$
\mathrm{BD}=1.02-0.156 \log (\mathrm{OM})\left(\mathrm{R}^{2}=0.45, \mathrm{RMSE}=0.26, n=642\right)
$$

The relationship between $\mathrm{OM}$ and bulk density for the soil in the database is given in Figure 2, which shows bulk density is decreasing with increasing OM content. The relationship for Andisols (Eq. 7) shows lower bulk density values compared to the other mineral soils. This is to be expected as Andisols are dominated by allophanic materials which have lower density. Applying equations (5), (6), and (7) to the Korean soil database provides an $R^{2}=0.49$ ( $\mathrm{n}=$ 108).

Figure 2 near here

We validated the bulk density PTF using the independent map validation dataset. Table 1 shows the validation statistics in terms of mean error (ME), root mean squared error (RMSE), and coefficient of determination $\left(\mathrm{R}^{2}\right)$. The results showed that the overall prediction error $\left(\mathrm{RMSE}=0.208 \mathrm{~g} \mathrm{~cm}^{-3}\right.$ ) is higher compared to values obtained by others. For example Martin et al. (2009) obtained an RMSE $=0.123 \mathrm{~g} \mathrm{~cm}^{-3}$ for soils from France and Tranter et al. (2007) obtained an RMSE $=0.195 \mathrm{~g} \mathrm{~cm}^{-3}$ for soils in Australia. However, our prediction is not biased (ME values close to 0). The prediction is considered reasonable in this context as the pedotransfer functions were calibrated from a limited observation $(n=108)$. The prediction for Andisols (Eq. 7) appeared to be useful with no bias and low RMSE.

PTF for field capacity and wilting point

From the Korean soil database, we derived a linear model predicting water content at $-10 \mathrm{kPa}$ $\left(\mathrm{w}_{10}\right)$ to represent field capacity:

$$
\begin{array}{r}
\mathrm{w}_{10}=33.18-0.188 \text { Sand }+0.918 \text { CEC }+3.578 \log (\mathrm{OM}) \\
\left(\mathrm{R}^{2}=0.66, \mathrm{RMSE}=8.02 \mathrm{~g} 100 \mathrm{~g}^{-1}, n=1203\right)
\end{array}
$$

Similarly, we derived another model for water content at $-1500 \mathrm{kPa}\left(\mathrm{w}_{1500}\right)$ to represent wilting point: 


$$
\begin{array}{r}
\mathrm{w}_{1500}=3.13+0.186 \text { Clay }+0.541 \text { CEC }+1.708 \log (\mathrm{OM}) \\
\left(\mathrm{R}^{2}=0.61, \mathrm{RMSE}=4.67 \mathrm{~g} 100 \mathrm{~g}^{-1}, n=1435\right)
\end{array}
$$

Note that these PTFs are based on measurements from ground samples with units in percentage mass $\left(\mathrm{g} 100 \mathrm{~g}^{-1}\right.$ ). The goodness of fit for these PTFs is shown in Supplementary Materials. These PTFs are used to fill the data gap of unmeasured $\mathrm{w}_{10}$ which are only $25 \%$ of the dataset, and unmeasured $\mathrm{w}_{1500}$ which constituted $10 \%$ of the data.

\section{Adjustment of Field Capacity}

Using the dataset from US National Soil Characterization database (Soil Survey Staff, 1997), a relationship between $\mathrm{w}_{10}$ clod and $\mathrm{w}_{10}$ ground is derived

$$
\begin{aligned}
& \mathrm{w}_{10 \text { clod }}=40.71+0.67 \mathrm{w}_{10 \text { ground }}-21.36 \mathrm{BD} \\
& \left(\mathrm{R}^{2}=0.81, \mathrm{RMSE}=4.45 \mathrm{~g} 100 \mathrm{~g}^{-1}, n=274\right)
\end{aligned}
$$

This model describes the reduction of soil water content with increasing bulk density (Figure 3). We validated this model on 27 soil samples in the US database that were not used for deriving the models. For water content at $-10 \mathrm{kPa}$, eq (10) gives an $\mathrm{R}^{2}=0.73$. It can be seen that our models predict very well the likely water retention at $-10 \mathrm{kPa}$ of clod samples given data obtained from disturbed soil samples. This equation allows the estimation of the representative water content at $-10 \mathrm{kPa}$ for a given bulk density.

Figure 3 near here

\section{Available water capacity}

Based on equations (5) to (10), volumetric water content $(\theta)$ at $-10 \mathrm{kPa},-1500 \mathrm{kPa}$, and their difference (AWC) were calculated for each soil series. Table 2 shows the predicted values of these soil properties grouped by soil order. Histosols show the highest water retention at -10 and -1500 kPa. Andisols, which are dominated by non-crystalline allophanic minerals, show the highest water storage capacity of $29 \%$, which is also known in the literature (Shoji et al., 1996). They also have the highest volumetric water content at field capacity (mean 56\%), and the volumetric water content at wilting point (mean 27\%). This pattern of high water 
retention is also observed by Fontes, Gonçalves \& Pereira (2004) and Pochet et al. (2007). As indicated by Shoji et al. (1996), one of the special characteristics of Andisols is their high water-holding capacity at $-1500 \mathrm{kPa}$. Entisols and Inceptisols which have loamy texture also show high water retention. The lowest water retention is Entisols which are dominated by sandy materials.

The predicted values were compared with measured AWC values from the US soil data in the Tempel, Batjes \& van Engelen (1996) database. Table 3 shows the AWC of the US soil data grouped by mineralogy and texture. For mineral soils, the highest water capacity is found in allophanic soils with a mean of $27 \%$, similar to our estimates (Table 2). Overall medium textured soils have higher AWC in both soil with low activity and high activity clay. These values are in accordance with our estimates for Korean soils.

Finally, PAWC (amount of available water that can be stored in the soil to $1 \mathrm{~m}$ ) was calculated using Eqn. (1) for the modal soil profiles of the 380 South Korean soil series. Table 4 shows the statistics of the estimates grouped by soil order. Note that the Mollisols and Histosols were excluded in this analysis as they are only represented by 2 soil series. The soils with the highest PAWC are the Ultisols and Alfisols (mean of 206 and 205 mm, respectively). Interestingly, Andisols appear to have a low PAWC, contradictory to the horizon measurement. The low values are due to the higher gravel content of Andisols which affected the calculation of PAWC.

\section{PAWC Map}

The value of PAWC for each of the soil series was then mapped onto the 1:25,000 soil map and shown in Figure 4. The western part of the country generally showed higher available water capacity than the eastern part of the country which is mountainous and has shallower soils. The mean value of PAWC (to $1 \mathrm{~m}$ depth) for Korean soil is $189 \mathrm{~mm}$. Total available water capacity is summarized by agricultural land use using a map provided by the Korean Ministry of Land, Transport, and Maritime Affairs. PAWC is the highest in paddy fields, with a mean of $231 \mathrm{~mm}$, which are mostly located in the fluvio-marine plain (See Supplementary Material). 
We also are able to display the volumetric water content at -10 and $-1500 \mathrm{kPa}$ down the profile as a continuous function using the equal-area spline. Examples for several soil series are shown in Supplementary Materials.

Figure 4 near here

\section{Map validation}

In this paper, each mapping unit (from 1:25,000) is represented by a soil series, and each soil series is represented by a modal profile. Obviously there is variability within a mapping unit, i.e. the soil is not homogenous. Here each soil series is only represented by a modal profile and we do not have an uncertainty measurement of the variability. In order to gauge the accuracy of the map, we compared the map prediction of bulk density, sand and clay content (which were used as inputs for prediction of AWC) with measured values from an independent dataset. Tables 5-7 shows the accuracy measure in terms of mean error (ME), root mean squared error (RMSE), and coefficient of determination $\left(\mathrm{R}^{2}\right)$.

The map of bulk density (Table 5 ) is realistic with an overall $\mathrm{R}^{2}$ value of 0.47 , and has the same magnitude of error compared to the pedotransfer prediction (Table 1). There is an indication that the prediction at the surface layer $(0-5) \mathrm{cm}$ is less accurate, as the surface layer is mostly affected by cultivation. Table 6 shows that the map predicts sand content very well with $\mathrm{R}^{2}$ values between 0.5 and 0.6 for all depths, meanwhile prediction of clay content (Table 7) is less accurate with $\mathrm{R}^{2}$ values between 0.2 and 0.5 .

Leenhardt et al. (1994) evaluated the accuracy of soil maps in an area of 1328 ha, the south of France. They showed that the $\mathrm{R}^{2}$ values, which were calculated as the proportions of variance explained by the 1: 25,000 soil map, for $\mathrm{w}_{10}, \mathrm{w}_{1500}$ bulk density, clay, and sand content are $0.77,0.71,0.73,0.62$, and 0.66 , respectively. In comparison, our validation shows lower $\mathrm{R}^{2}$ values for bulk density, clay, and sand content $\left(\mathrm{R}^{2}\right.$ values of $0.47,0.56$, and 0.40$)$. Nevertheless, Henderson et al. (2005) obtained lower $\mathrm{R}^{2}$ values of 0.44 for the surface soil and 0.22 for sub soil prediction of clay content in Australia. The accuracy of prediction depends on the sampling strategy, landscape condition, extent, and resolution. Nevertheless, the validation of these maps show values that are comparable to other studies which used digital soil mapping techniques employing empirical models that relate soil observations and environmental covariates (Liu et al., 2012; McBratney, Mendonça Santos \& Minasny, 2003). 
To test the accuracy of the predicted water content at -10 kPa (field capacity), we compared the prediction of 7 soil series with an independent water retention dataset. Figure 5a shows that the prediction has an $\mathrm{R}^{2}=0.61$, and $\mathrm{RMSE}=6.3 \%$, which is comparable with values reported by other researchers. Wösten et al. (2001) showed that the RMSE values for the prediction of water content at -10 and $-33 \mathrm{kPa}$ based on various studies are between 3 and $7 \%$. Because of water retention is rarely measured in Korean surveys, the validation can only be done on a limited soil samples. Nevertheless, Figure 5b shows an example of the measured and predicted PAWC for a profile from Songjeong soil series. The profile is a fine loamy, mesic family of Typic Hapludults, with measurement collected from soil core samples from Ap1, B1, and C horizons, located in an apple research orchard field at the College of Agriculture and Life Science, Seoul National University, in Suwon. Although there is variation in the depth of the horizons with the modal profile, the prediction of water content at -10 and $-1500 \mathrm{kPa}$ fits reasonably well with the measured data.

Figure 5 near here

\section{Conclusions}

This work demonstrated the derivation of a soil AWC map in Korea using information from conventional soil survey, and soil map integrated in digital mapping procedures. The process is not straightforward as there are hiatus between what is available in the soil database and what is required. Thus it required the derivation of pedotransfer functions for bulk density, field capacity and wilting point. Further there is another problem on the use of ground soil samples in measuring field capacity. These substantial data gaps required the derivation of pedotransfer functions from different data sources. The price to be paid for these knowledge gaps is uncertainty in the predictions. The uncertainty in the PTF models mostly comes from uncertainty in estimating $\mathrm{BD}$, followed by estimating water content at $-10 \mathrm{kPa}$ from ground samples. The other variables have the lowest uncertainty (PTFs for $\mathrm{w}_{10}$ and $\mathrm{W}_{1500}$ ) as demonstrated by the higher accuracy of prediction and they are only used in $10-25 \%$ of the data.

Validation of the 1:25,000 soil map showed that bulk density, clay, and sand content maps show that the maps can capture 40 to $55 \%$ of the soil variability, which is what is to be expected on digital soil maps. We haven't been able to fully validate the AWC map or derive 
estimates of uncertainty for the map predictions. Uncertainty of the map has several components: uncertainty in the soil map, the representativeness of the modal soil profile, and finally the accuracy of the pedotransfer functions. All these need to be validated, however we do not have enough resources to collect new samples and analyse the water retention relationships. Because of the measurement of water retention on undisturbed cores is time consuming and expensive, it is rarely gauged in Korean survey. The only available data came from a limited number of soil physics experiments. Nevertheless an examination of the predictability of water content at $-10 \mathrm{kPa}$ on a limited soil series, indicated a reasonable prediction $\left(\mathrm{R}^{2}=0.60\right)$.

We used water content at $-10 \mathrm{kPa}$ as the upper limit of available water or field capacity. In reality, field capacity is more of a process-dependent parameter, i.e. it depends on soil-water flow (Romano, Palladino \& Chirico, 2011). Future work needs to measure the field capacity values in the field in the dominant soil types of the study area. There are also problems dealing with Andisols. They can desiccate if dried from $1 \mathrm{kPa}$ to $1500 \mathrm{kPa}$ which leads to significant shrinkage (Dorel et al., 2000).

This map gives an indication of PAWC based on the South Korean soil series and a detailed soil map. It will enable us to perform functional evaluation such as running simulation models to predict potential evapotranspiration. This map should provide more detailed and accurate AWC data for hydrological models than global maps of AWC such as the one produced by Dunne \& Willmott (1996) or Batjes (1996) that were based on FAO soil classes.

\section{Acknowledgements}

The authors thank Dr. Nathan Odgers for his suggestions on the draft manuscript. Budiman Minasny is funded by the ARC QEII fellowship.

\section{References}


Adams, W.A., (1973) The effect of organic matter on the bulk and true densities of some uncultivated podzolic soils. J. Soil Sci., 24, 10-17.

Aina, P.O., Periaswamy, S.P., (1985) Estimating available water-holding capacity of western Nigerian soils from soil texture and bulk density, using core and sieved samples. Soil Science, 140, 55-58.

Basson, C.H., Terblanche, J.S., (2010) Metabolic responses of Glossina pallidipes (Diptera: Glossinidae) puparia exposed to oxygen and temperature variation: Implications for population dynamics and subterranean life. Journal of Insect Physiology, 56, 1789-1797.

Batjes, N.H., (1996) Development of a world data set of soil water retention properties using pedotransfer rules. Geoderma, 71, 31-52.

Bell, M.A., Van Keulen, H., (1996) Effect of soil disturbance on pedotransfer function development for field capacity. Soil Technology, 8, 321-329.

Cazemier, D.R., Lagacherie, P., Martin-Clouaire, R., (2001) A possibility theory approach for estimating available water capacity from imprecise information contained in soil databases. Geoderma, 103, 113-132.

Dorel, M., Roger-Estrade, J., Manichon, H., Delvaux, B., (2000) Porosity and soil water properties of Caribbean volcanic ash soils. Soil Use and Management, 16, 133-140.

Dunne, K.A., Willmott, C.J., (1996) Global distribution of plant-extractable water capacity of soil. International Journal of Climatology, 16, 841-859.

Fontes, J.C., Gonçalves, M.C., Pereira, L.S., (2004) Andosols of Terceira, Azores: Measurement and significance of soil hydraulic properties. Catena, 56, 145-154.

Han, K. H., H. M. Ro, H. J. Cho, L.Y. Kim , S. W. Hwang, H. R. Cho, and K. C. Song. 2008a. Unsaturated hydraulic conductivity functions of van Genuchten's and Campbell's models tested by one-step outflow method through tempe pressure cell. Korean Journal of Soil Science and Fertilizer. 41, 273-278.

Han, K. H., L.Y. Kim , H. J. Cho, Y.B. Im, S.W. Hwang, H.M. Ro. 2008b. A study on the change of organic carbon content and structure of soils. Bull. of Agro-Environment Research, pp. 1210-1214, National Academy of Agricultural Science. Suwon. Repulic of Korea.

Hartemink, A.E., (2008) Soils are back on the global agenda. Soil Use and Management, 24, 327-330.

Hartemink, A.E., McBratney, A., (2008) A soil science renaissance. Geoderma, 148, 123-129.

Henderson, B.L., Bui, E.N., Moran, C.J., Simon, D.A.P., (2005) Australia-wide predictions of soil properties using decision trees. Geoderma, 124, 383-398.

Holmes, K.W., Roberts, D.A., Sweeney, S., Numata, I., Matricardi, E., Biggs, T.W., Batista, G., Chadwick, O.A., (2004) Soil databases and the problem of establishing regional biogeochemical trends. Global Change Biology, 10, 796-814.

Jung, K.H., Kim, W.T., Hur, S.O., Jung, P.K., Jung, Y.S., (2004) USLE/RUSLE factors for national scale soil loss estimation based on the digital detailed soil map. Korean Journal of Soil Science and Fertilizer 37, 199-206.

Jung, K.H., Son, Y.K., Hong, S.Y., Hur, S.O., Ha, S.K., (2005) Assessment of national soil loss and potential erosion area using the digital detailed soil maps. Korean Journal of Soil Science and Fertilizer 38, 59-65.

Kern, J.S., (1995) Geographic patterns of soil water-holding capacity in the contiguous United States. Soil Science Society of America Journal, 59, 1126-1133.

Knorr, W., Heimann, M., (2001) Uncertainlies in global terrestrial biosphere modeling 1. A comprehensive sensitivity analysis with a new photosynthesis and energy balance scheme. Global Biogeochemical Cycles, 15, 207-225.

Lee, S., Song, K.Y., Oh, H.J., Choi, J., (2012) Detection of landslides using web-based aerial photographs and landslide susceptibility mapping using geospatial analysis. International Journal of Remote Sensing, 33, 4937-4966. 
Leenhardt, D., Voltz, M., Bornand, M., Webster, R., (1994) Evaluating soil maps for prediction of soil water properties. European Journal of Soil Science, 45, 293-301.

Liu, F., Geng, X., Zhu, A.X., Fraser, W., Waddell, A., (2012) Soil texture mapping over low relief areas using land surface feedback dynamic patterns extracted from MODIS. Geoderma, 171-172, 44-52.

Malone, B.P., McBratney, A.B., Minasny, B., Laslett, G.M., (2009) Mapping continuous depth functions of soil carbon storage and available water capacity. Geoderma, 154, 138-152.

Martin, M.P., Lo Seen, D., Boulonne, L., Jolivet, C., Nair, K.M., Bourgeon, G., Arrouays, D., (2009) Optimizing pedotransfer functions for estimating soil bulk density using boosted regression trees. Soil Science Society of America Journal, 73, 485-493.

McBratney, A.B., Mendonça Santos, M.L., Minasny, B., (2003) On digital soil mapping. Geoderma, 117, 3-52.

McBratney, A.B., Minasny, B., Cattle, S.R., Vervoort, R.W., (2002) From pedotransfer functions to soil inference systems. Geoderma, 109, 41-73.

Milly, P.C.D., Shmakin, A.B., (2002) Global modeling of land water and energy balances. Part I: The land dynamics (LaD) model. Journal of Hydrometeorology, 3, 283-299.

Mulder, V.L., de Bruin, S., Schaepman, M.E., Mayr, T.R., (2011) The use of remote sensing in soil and terrain mapping - A review. Geoderma, 162, 1-19.

Nemes, A., Pachepsky, Y.A., Timlin, D.J., (2011) Toward improving global estimates of field soil water capacity. Soil Science Society of America Journal, 75, 807-812.

NIAST, (2000). Taxonomical Classification of Korean Soils. National Institute of Agricultural Sciences and Technology, Rural Development Administration (RDA), Suwon, Republic of Korea.

Nijssen, B., O'Donnell, G.M., Lettenmaier, D.P., Lohmann, D., Wood, E.F., (2001) Predicting the discharge of global rivers. Journal of Climate, 14, 3307-3323.

Park, S., Oh, C., Jeon, S., Jung, H., Choi, C., (2011) Soil erosion risk in Korean watersheds, assessed using the revised universal soil loss equation. Journal of Hydrology, 399, 263-273.

Piedallu, C., Gégout, J.C., Bruand, A., Seynave, I., (2011) Mapping soil water holding capacity over large areas to predict potential production of forest stands. Geoderma, 160, 355-366.

Pochet, G., Van der Velde, M., Vanclooster, M., Delvaux, B., (2007) Hydric properties of high charge, halloysitic clay soils from the tropical South Pacific region. Geoderma, 138, 96-109.

Poggio, L., Gimona, A., Brown, I., Castellazzi, M., (2010) Soil available water capacity interpolation and spatial uncertainty modelling at multiple geographical extents. Geoderma, 160, 175-188.

Romano, N., Palladino, M., Chirico, G.B., (2011) Parameterization of a bucket model for soil-vegetation-atmosphere modeling under seasonal climatic regimes. Hydrology and Earth System Sciences, 15, 3877-3893.

Sanchez, P.A., Ahamed, S., Carré, F., Hartemink, A.E., Hempel, J., Huising, J., Lagacherie, P., McBratney, A.B., McKenzie, N.J., De Lourdes Mendonça-Santos, M., Minasny, B., Montanarella, L., Okoth, P., Palm, C.A., Sachs, J.D., Shepherd, K.D., Vågen, T.G., Vanlauwe, B., Walsh, M.G., Winowiecki, L.A., Zhang, G.L., (2009) Digital soil map of the world. Science, 325, 680-681.

Saxton, K.E., Rawls, W.J., (2006) Soil water characteristic estimates by texture and organic matter for hydrologic solutions. Soil Science Society of America Journal, 70, 1569-1578. 
Sharma, M.L., Uehara, G., (1968) Influence of soil structure on water relations in low humic latosols: I. Water retention. Soil Science Society of America Proceedings, 32, 765-770.

Shoji, S., Nanzyo, M., Dahlgren, R.A., Quantin, P., (1996) Evaluation and proposed revisions of criteria for Andosols in the World Reference Base for Soil Resources. Soil Science, 161, 604-615.

Soil Survey Staff (1997). National Characterization Data, Soil Survey Laboratory, Lincoln, NE.

Tao, F., Yokozawa, M., Hayashi, Y., Lin, E., (2003) Terrestrial water cycle and the impact of climate change. Ambio, 32, 295-301.

Tempel, P., Batjes, N.H., van Engelen, V.W.P., (1996) IGBP-DIS Soil Data Set for Pedotransfer Function Development, Wageningen.

Terribile, F., Coppola, A., Langella, G., Martina, M., Basile, A., (2011) Potential and limitations of using soil mapping information to understand landscape hydrology. Hydrology and Earth System Sciences, 15, 3895-3933.

Tranter, G., Minasny, B., McBratney, A.B., Murphy, B., McKenzie, N.J., Grundy, M., Brough, D., (2007) Building and testing conceptual and empirical models for predicting soil bulk density. Soil Use and Management, 23, 437-443.

Triantafilis, J., Kerridge, B., Buchanan, S.M., (2009) Digital soil-class mapping from proximal and remotely sensed data at the field level. Agronomy Journal, 101, 841-853.

Walter, B.P., Heimann, M., Matthews, E., (2001) Modeling modern methane emissions from natural wetlands 1 . Model description and results. Journal of Geophysical Research D: Atmospheres, 106, 34189-34206.

Wösten, J.H.M., Pachepsky, Ya.A., Rawls, W.J. (2001) Pedotransfer functions: bridging the gap between available basic soil data and missing soil hydraulic characteristics. Journal of Hydrology, 251, 123-150.

Wösten, J.H.M., Verzandvoort, S.J.E., Leenaars, J.G.B., Hoogland, T., Wesseling, J.G., (2013). Soil hydraulic information for river basin studies in semi-arid regions. Geoderma 195-196, 79-86

Zheng, D., Hunt, E.R., Running, S., W., (1996) Comparison of available soil water capacity estimated from topography and soil series information. Landscape Ecology, 11, 3-14. 


\section{Figure Captions}

Figure 1. Procedure for estimation and mapping of profile available water capacity (PAWC) in Korea.

Figure 2. The relationship between organic matter content and bulk density predicted using pedotransfer functions. The red circles are values predicted for Andisols(Eq. 6) and the black circles are values predicted for other mineral soils (Eqs. 4 \& 5).

Figure 3. (a) Response surface of predicted water retention for clods given water retention of ground samples and bulk density, (b) the goodness of fit of the relationship.

Figure 4. Map of Korean soil profile available water capacity to $1 \mathrm{~m}$ (in mm).

Figure 5. (a) Measured vs. predicted volumetric water content at $-10 \mathrm{kPa}$ on a validation dataset. (b) Measured (blue lines) and predicted (red lines) water retention at -10 and -1500 $\mathrm{kPa}$ for a soil profile of Songjeon soil series. The shaded area represents the standard deviation of the water content measurement (of 5 replicates). 


\section{Table $\mathbf{1}_{\text {(on next page) }}$}

Tables 
Table 1. Prediction accuracy for bulk density PTF tested against an independent dataset, $\mathrm{n}$ refers to the number of observations, ME refers to mean error, RMSE is the root mean squared error.

\begin{tabular}{lllll}
\hline Soil & $\mathrm{n}$ & $\mathrm{ME}\left(\mathrm{g} / \mathrm{cm}^{3}\right)$ & $\mathrm{RMSE}\left(\mathrm{g} / \mathrm{cm}^{3}\right)$ & $\mathrm{R}^{2}$ \\
\hline All & 426 & -0.0890 & 0.208 & 0.67 \\
Andisols & 56 & -0.0001 & 0.154 & 0.63 \\
Other & 370 & -0.1026 & 0.215 & 0.42 \\
\hline
\end{tabular}


Table 2. The statistics of predicted volumetric water content $\theta$ at field capacity, wilting point and its difference (in percent volume) from all soil horizons grouped based on soil order in Korea.

\begin{tabular}{|c|c|c|c|c|c|c|c|}
\hline & \multirow[b]{2}{*}{$\mathrm{n}$} & \multicolumn{2}{|c|}{$\theta-10 \mathrm{kPa}$} & \multicolumn{2}{|c|}{$\theta-1500 \mathrm{kPa}$} & \multicolumn{2}{|c|}{$\theta_{10}-\theta_{1500}$} \\
\hline & & Mean & dev. & Mean & dev. & Mean & dev. \\
\hline Alfisols & 211 & 36.1 & 8.3 & 14.4 & 5.7 & 21.7 & 7.2 \\
\hline Andisols & 109 & 56.4 & 13.0 & 27.0 & 11.0 & 29.4 & 7.0 \\
\hline Entisols & 184 & 24.7 & 10.1 & 8.1 & 5.4 & 16.6 & 7.2 \\
\hline $\begin{array}{l}\text { Histosols } \\
\text { Inceptisol }\end{array}$ & 10 & 57.1 & 19.0 & 30.1 & 7.0 & 27.0 & 12.6 \\
\hline S & 946 & 33.5 & 8.6 & 12.5 & 5.8 & 21.0 & 6.9 \\
\hline Mollisols & 6 & 19.3 & 11.6 & 5.1 & 3.1 & 14.2 & 8.5 \\
\hline Ultisols & 133 & 35.9 & 7.3 & 15.2 & 5.1 & 20.7 & 7.3 \\
\hline
\end{tabular}


Table 3. Mean followed by standard deviation of the amount of water between field capacity and wilting point (in percent volume), number in brackets represent the number of samples, based on the US soil data in Tempel et al. (1997).

\begin{tabular}{|c|c|c|c|c|}
\hline Mineralogy* & & $\begin{array}{r}\text { Coarse } \\
\text { textured }\end{array}$ & $\begin{array}{l}\text { Medium } \\
\text { textured }\end{array}$ & $\begin{array}{r}\text { Fine } \\
\text { textured }\end{array}$ \\
\hline & & $10.5 \pm 19.9$ & $16.2 \pm 11.3$ & $11.3 \pm 6.4$ \\
\hline Low activity clay & & $\begin{array}{r}(5,274) \\
17.2 \pm 9.6\end{array}$ & $\begin{array}{r}(14,541) \\
24.0 \pm 28.9\end{array}$ & $\begin{array}{r}(2,663) \\
18.4 \pm 15.1\end{array}$ \\
\hline High activity clay & & $\begin{array}{r}(103) \\
19.0 \pm 14.5\end{array}$ & $\begin{array}{r}(14) \\
16.8 \pm 13.0\end{array}$ & $\begin{array}{r}(50) \\
14.4 \pm 7.0\end{array}$ \\
\hline Mixed activity clay & $134.4 \pm 737$ & (328) & $(5,442)$ & $(5,750)$ \\
\hline Organic & $\begin{array}{r}(184) \\
27.1 \pm 14.3\end{array}$ & & & \\
\hline Allophane & $\begin{array}{r}(603) \\
15.0 \pm 8.9\end{array}$ & & & \\
\hline Not specified & (3534) & & & \\
\hline
\end{tabular}

*Low activity clay is defined for soils with CEC $<200 \mathrm{mmol} / \mathrm{kg}$, Mixed: between 200 and $620 \mathrm{mmol} / \mathrm{kg}$, High activity $>620 \mathrm{mmol} / \mathrm{kg}$. Organic soils if Organic C content $>16 \%$. 
Table 4. The statistics of PAWC (profile available water capacity) in Korea grouped based on soil order. The average is value is based on the area covered by the map.

\begin{tabular}{lrcc}
\hline & \multicolumn{1}{c}{$\begin{array}{l}\text { Area } \\
\left(\mathrm{km}^{2}\right)\end{array}$} & \multicolumn{2}{c}{ PAWC (mm) } \\
& & Mean & Std. dev. \\
\hline Alfisols & 3,474 & 205 & 27 \\
Andisols & 1,394 & 138 & 54 \\
Entisols & 14,291 & 149 & 73 \\
Inceptisols & 70,868 & 192 & 55 \\
Ultisols & 4,736 & 206 & 55 \\
\hline
\end{tabular}


Table 5. Prediction accuracy for mapped bulk density tested against an independent dataset, $\mathrm{n}$ refers to the number of observations, ME refers to mean error, RMSE is the root mean squared error, and $\mathrm{R}^{2}$ is the coefficient of determination.

\begin{tabular}{ccccc}
\hline $\begin{array}{c}\text { Depth } \\
\text { intervals } \\
(\mathrm{cm})\end{array}$ & $\mathrm{n}$ & $\begin{array}{c}\mathrm{ME} \\
\left(\mathrm{g} / \mathrm{cm}^{3}\right)\end{array}$ & $\begin{array}{c}\mathrm{RMSE} \\
\left(\mathrm{g} / \mathrm{cm}^{3}\right)\end{array}$ & $\mathrm{R}^{2}$ \\
\hline $0-5$ & 111 & 0.013 & 0.225 & 0.36 \\
$5-15$ & 111 & -0.002 & 0.221 & 0.41 \\
$15-30$ & 113 & -0.057 & 0.252 & 0.47 \\
$30-60$ & 111 & -0.059 & 0.260 & 0.44 \\
$60-100$ & 98 & -0.057 & 0.238 & 0.43 \\
& & & & \\
$0-100$ & 566 & -0.032 & 0.239 & 0.47 \\
\hline
\end{tabular}


Table 6. Prediction accuracy for mapped sand content tested against an independent dataset, $\mathrm{n}$ refers to the number of observations, ME refers to mean error, RMSE is the root mean squared error, and $\mathrm{R}^{2}$ is the coefficient of determination.

\begin{tabular}{|c|c|c|c|c|}
\hline $\begin{array}{c}\text { Depth } \\
\text { intervals } \\
(\mathrm{cm})\end{array}$ & $\mathrm{n}$ & $\begin{array}{c}\text { ME } \\
(\mathrm{g} / 100 \mathrm{~g})\end{array}$ & $\begin{array}{c}\text { RMSE } \\
\text { (g/100 g) }\end{array}$ & $\mathrm{R}^{2}$ \\
\hline $0-5$ & 167 & 3.26 & 16.1 & 0.53 \\
\hline $5-15$ & 167 & 3.62 & 15.6 & 0.55 \\
\hline $15-30$ & 167 & 3.46 & 15.3 & 0.57 \\
\hline $30-60$ & 163 & 2.60 & 15.3 & 0.60 \\
\hline 60-100 & 167 & 3.26 & 16.1 & 0.53 \\
\hline $0-100$ & 831 & 3.50 & 16.0 & 0.56 \\
\hline
\end{tabular}


Table 7. Prediction accuracy for mapped clay content tested against an independent dataset, $\mathrm{n}$ refers to the number of observations, ME refers to mean error, RMSE is the root mean squared error, and $\mathrm{R}^{2}$ is the coefficient of determination.

\begin{tabular}{|c|c|c|c|c|}
\hline $\begin{array}{c}\text { Depth } \\
\text { intervals } \\
(\mathrm{cm})\end{array}$ & $\mathrm{n}$ & $\begin{array}{c}\text { ME } \\
\text { (g/100 g) }\end{array}$ & $\begin{array}{c}\text { RMSE } \\
\text { (g/100 g) }\end{array}$ & $\mathrm{R}^{2}$ \\
\hline $0-5$ & 167 & -2.00 & 9.05 & 0.24 \\
\hline $5-15$ & 167 & -2.06 & 8.53 & 0.29 \\
\hline $15-30$ & 167 & -1.73 & 8.46 & 0.40 \\
\hline $30-60$ & 163 & -1.71 & 8.46 & 0.52 \\
\hline $60-100$ & 150 & -2.06 & 9.79 & 0.46 \\
\hline $0-100$ & 814 & -1.90 & 8.86 & 0.40 \\
\hline
\end{tabular}




\section{Figure 1}

Figure 2

The relationship between organic matter content and bulk density predicted using pedotransfer functions. The red circles are values predicted for Andisols(Eq. 6) and the black circles are values predicted for other mineral soils (Eqs. 4 \& 5).

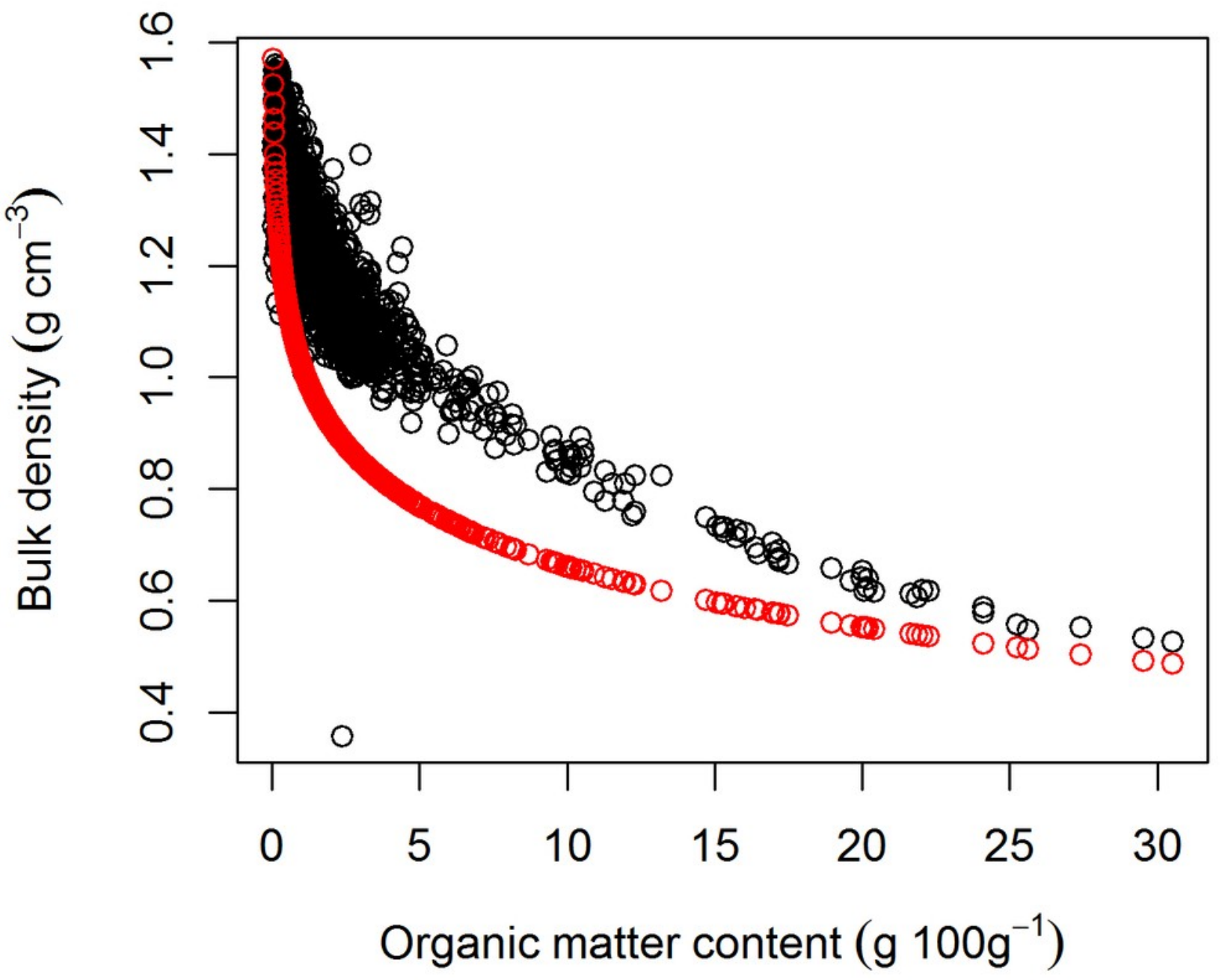




\section{Figure 2}

Figure 3

(a) Response surface of predicted water retention for clods given water retention of ground samples and bulk density, (b) the goodness of fit of the relationship.

(a)

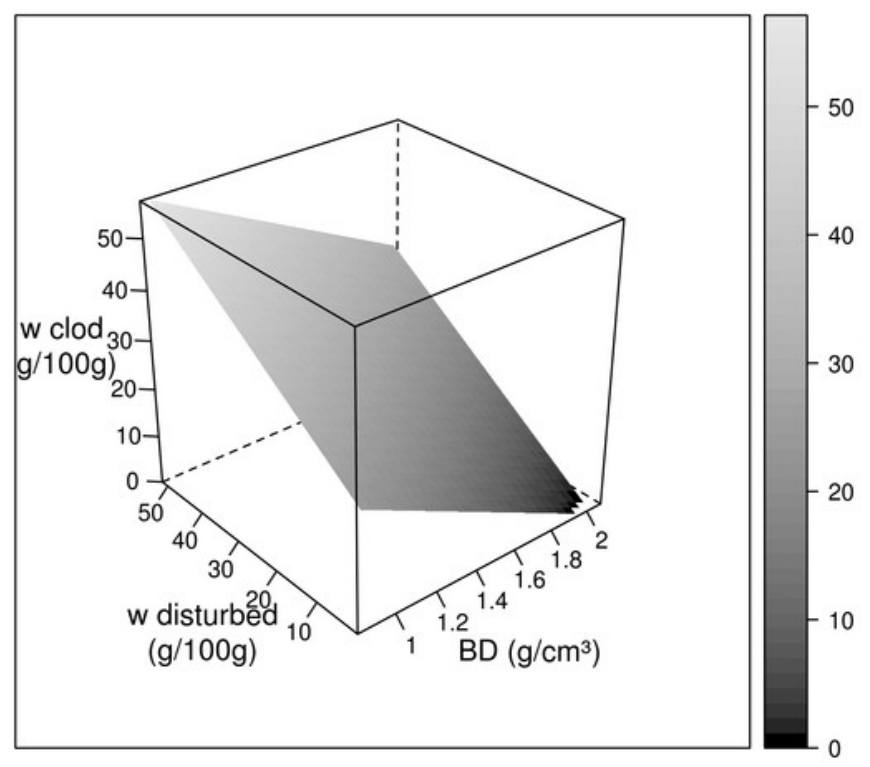

(b)

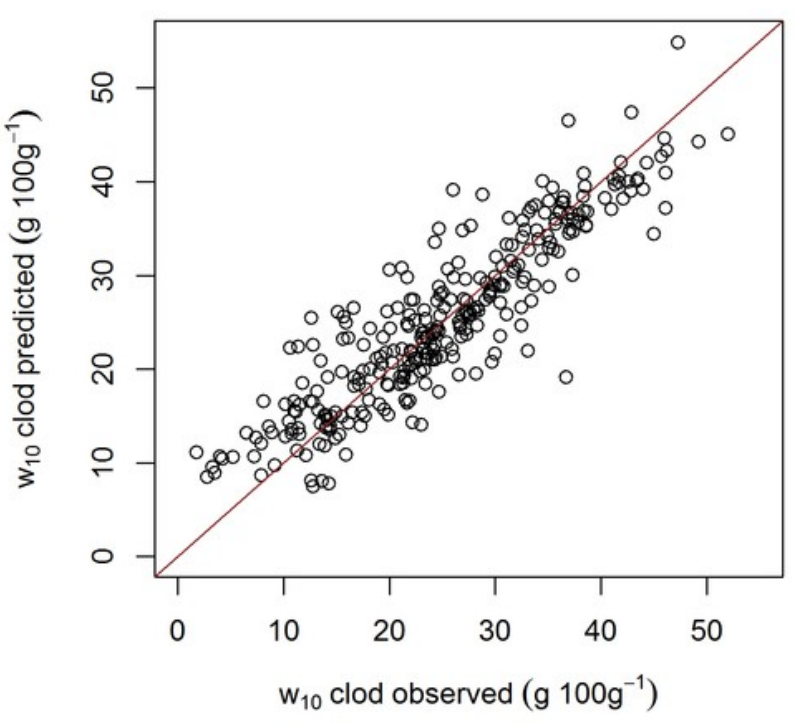




\section{Figure 3}

Figure 4

Map of Korean soil profile available water capacity to $1 \mathrm{~m}$ (in mm). 


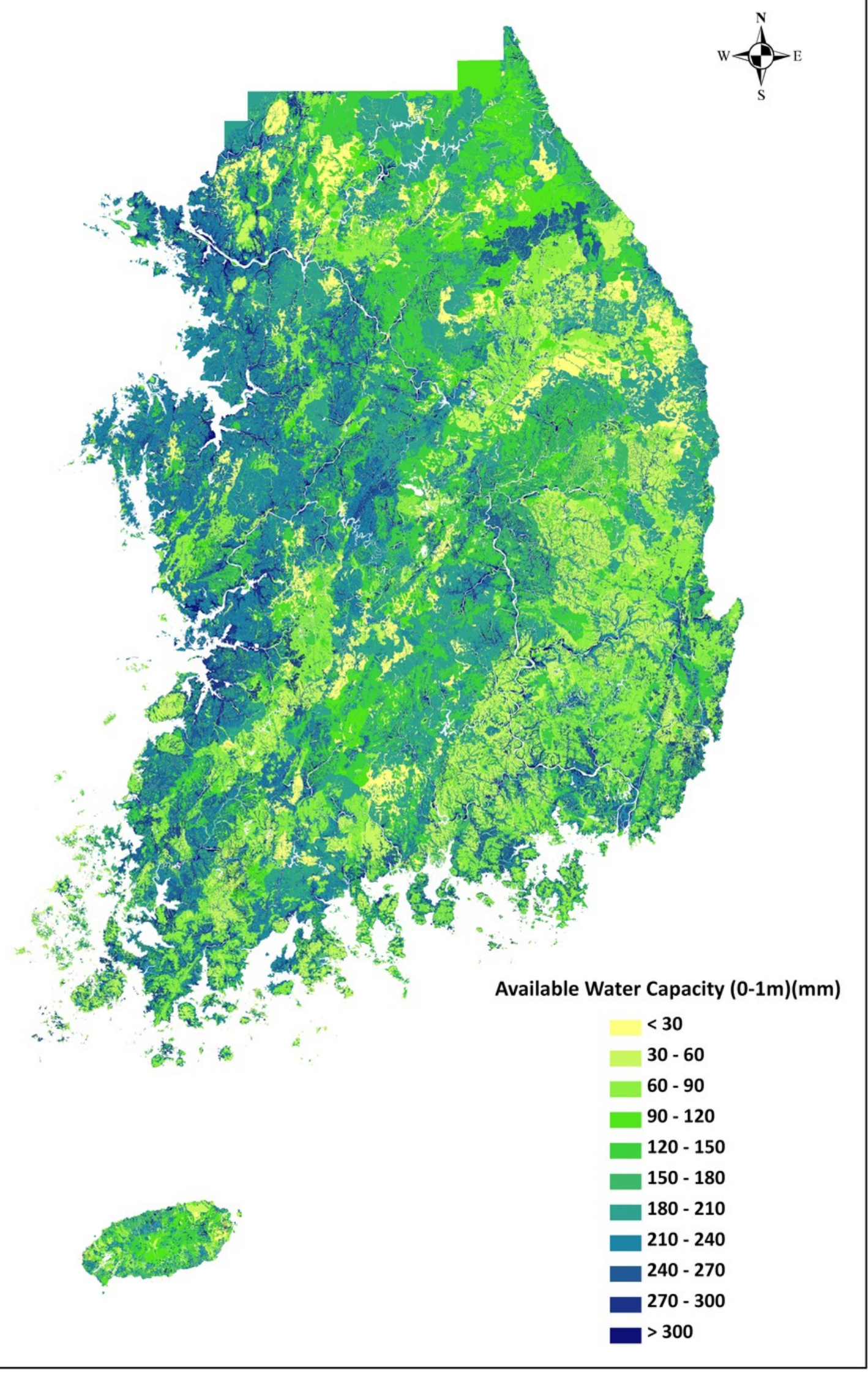




\section{Figure 4}

Figure 5

(a) Measured vs. predicted volumetric water content at $-10 \mathrm{kPa}$ on a validation dataset. (b) Measured (blue lines) and predicted (red lines) water retention at -10 and -1500 kPa for a soil profile of Songjeon soil series. The shaded area represents the standard deviation of the water content measurement (of 5 replicates).

(a)

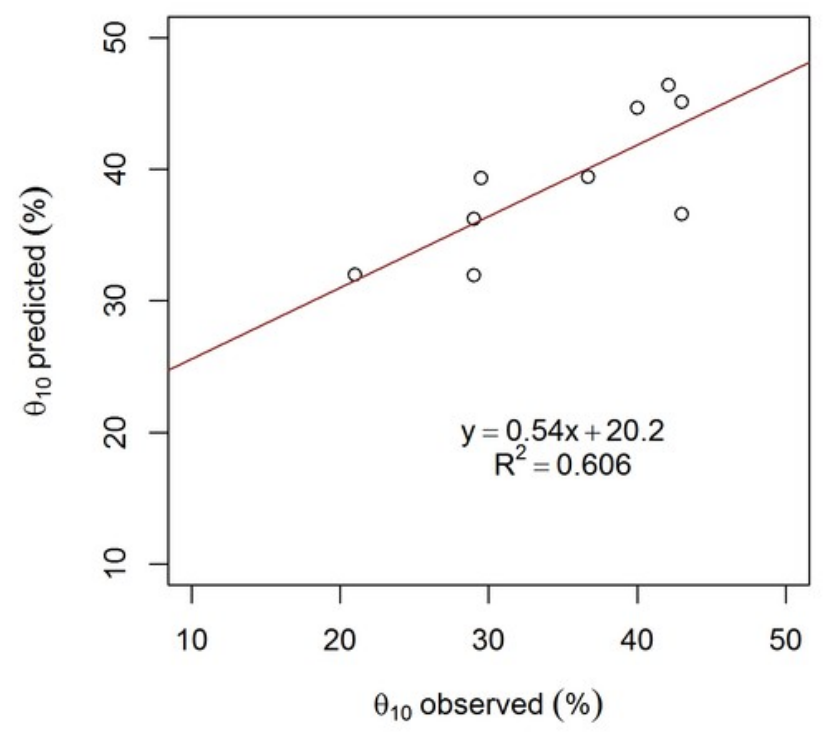

(b)

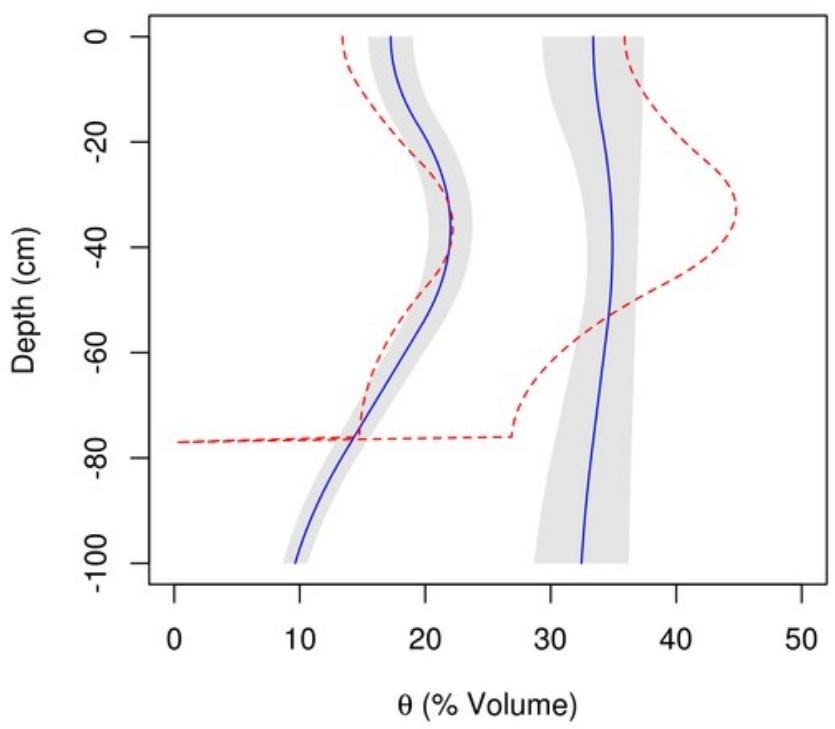




\section{Figure 5}

Figure 1

Procedure for estimation and mapping of profile available water capacity (PAWC) in Korea.

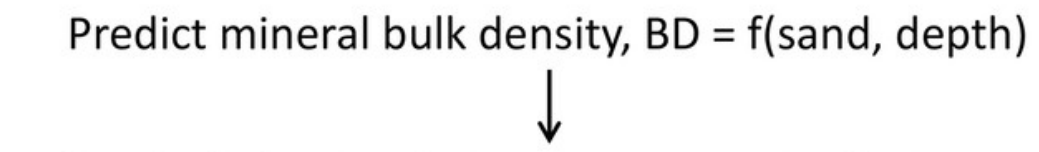

Adjust bulk density for $\mathrm{OM}$ content, $\mathrm{BD}=\mathrm{f}\left(\mathrm{BD}_{\min }, \mathrm{OM}\right)$

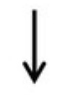

Measured $w$ at $-10 \mathrm{kPa}$ ?

PTF: $w$ at $-10 \mathrm{kPa}$ (\% mass) ground sample $\mathrm{W}_{10 \mathrm{gr}}=\mathrm{f}$ (sand, OM, CEC)

$\downarrow$

Adjust $w$ at $-10 \mathrm{kPa}$ (\% mass) from disturbed samples to include effect of BD

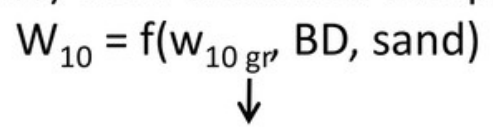

Measured $w$ at $-1500 \mathrm{kPa}$ ?

PTF w -1500 kPa (\% mass) disturbed sample

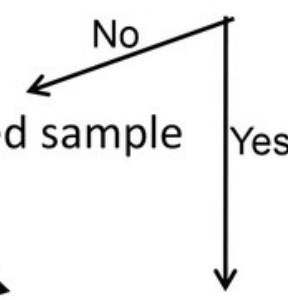

Adjust for gravel content

$$
\begin{gathered}
\mathrm{W}_{1500}=\mathrm{f}(\mathrm{clay,} \mathrm{OM}, \mathrm{CEC}) \\
\operatorname{AWC}(\mathrm{mm})=\mathrm{BD} \times\left(\mathrm{w}_{10}-\mathrm{w}_{1500}\right) / 100 \times \text { Thick } \\
\qquad \mathrm{PAWC}=\Sigma \mathrm{AWC} \text { (horizon) }
\end{gathered}
$$
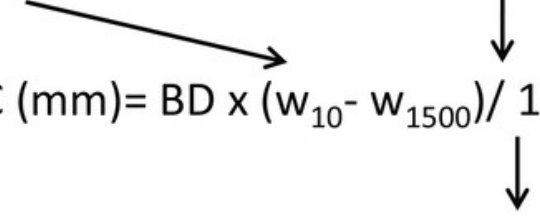

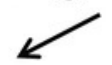

AWC $(\mathrm{mm})=B D \times\left(w_{10}-w_{1500}\right) / 100 \times$ Thickness of layer $(\mathrm{mm})$ 